\title{
Regulation Authority toward Management and Conflict Resolution on Private Higher Education
}

\author{
Sulaksono $^{1}$, Sudarsono $^{2}$, I nyoman Nurjaya ${ }^{2}$, A Rachmad Budiono $^{2}$ \\ ${ }^{1}$ Doctoral Candidates at faculty of law, Brawijaya University; Indonesia \\ ${ }^{2}$ Professor at Faculty of Law, Brawijaya University; Indonesia
}

\begin{abstract}
To create management order of private higher education, the government gradually began to organize it through the legislation. Education Law emphasizes that education must be conducted in a democratic and fair and not discriminatory to uphold human rights, religious values, cultural values, nation diversity. In the real condition, the setting of higher education in Indonesia since the beginning of independent day till nowadays are constantly changing concerning the times and to meet national needs. However, the Things should never change the historical setting of higher education form is the goals of higher education is the country's social mission (public services) are placed citizen as a state authority (governmental authority).
\end{abstract}

Keywords: Regulation of Authority, PTS Management, Conflict Resolution

\section{Introduction}

Etymologically, higher education consists of two syllables, education and higher. Based on Indonesian dictionary (KBBI), the word "Pendidikan" (Education) comes from the word 'Didik' which got prefix "pe" and the suffix "an", then these words bring the meaning to the process or method or act of educating. In language, the definition of education is the process of changing attitudes and behavior procedures toward groups of people in human mature by teaching and training efforts. [1]

Ki HajarDewantara as the Indonesian Education Leaderlaying a solid foundation of national progressive education for present and future generations formulated the definition of education as follows: "Education generally has meant the efforts to promote the growth of manners (inner strength, character), mind (intellect and the body of the child); those should not be separated away from the students so that we advance the perfection of life, and livelihood of our children who are students, in harmony with the world". [2]

The Definition of education based on the Law No.20/2003 on National Education System (hereinafter referred to Education law) is a conscious and deliberate effort to create an atmosphere of learning and the learning process so that learners actively developing their potential aspects to having the spiritual power of religion, self-control, personality, intelligence, pure character, and skills needed him and society (article 1 general requirement of education law). [3]

Through the explanation above, concluded, higher education has a sense as the education after secondary school [4]. In the Higher Education Act, higher education is the education stage after secondary school including educational programs of diploma, bachelor's, master's, specialist, and doctoral degrees which organized by higher education. Higher education organized in open system. Meanwhile, the college is one ofproviderunit concerning in higher education. Learners are called student-college, whereas the college educators are called lecturers.

Regarding on the fourth pillars of Nationality (Pancasila, the 1945 Constitution, the Republic of Indonesia, and the Unity in Diversity), Higher Education carried out or organized by references to the basis and the principle like what had been implemented by the Higher Education (Higher Education Organizer) [5]. In the context of the national education system, higher education is a cornerstone principle standing and upholding an educational activity in carrying out its role in society. The principles of higher education(in accordance with the Article 3 Law No. 12/2012) are the scientific truth; reasoning; honesty; justice; benefits; virtue; responsible; diversity; and affordability.

College as the provider of higher education is the subsystem of the national education system. The college is the educational unit that organizes higher education. In the field of education and science development, College has freedom of applicable academic and academic forum as well as the autonomy of science. Furthermore, the university has the autonomy to manage its own institution as a center of higher education, scientific research, and community service (laws No. 12/2012). [6]

In the other hand, college quality determines how the strong and qualify of the national education system, it is also influenced by the way of college organizer uphold height quality. Hence, It is impossible college quality would be increased when the organizer is not qualified. Whereas, when the condition come true, the national education goals will not be achieved as well as the national education system will be disrupted. 
Therefore, the position of higher education is very important in implementing higher education as the highest level of formal education, so that higher education is the last formal education process undergone by humans which determine the national education goals. Higher education obviously can improve the quality of human capital or intellectual capital, so that the national education system can build a human quality that can take part significantly for the increased quality of life in society and nation's development progress to the country become strong and civilized.

Based on the type, the college is divided into two; first, state university (hereinafter referred to as "PTN") is a higher education organized by the government, second, private university (hereinafter referred to as "PTS") is a higher education organized by private parties. Concerning to Government Regulation No.4/2014 PTN is established by the Government, while the PTS was founded by people with forming legal Operating Body principled non-profit entities and must have a permission of ministry of higher education and culture.

The college term that may be established by the community, such as(Article 59 section (1) of Act 12/2012): university, institute, high School, polytechnic, Academy, and a community college. Then, the requirement to establish a college (PTS) is regulated in Article 60 of Law 12/2012, as below:

1. PTS was founded by legal forming organizing body principled non-profit and must obtain the permission of the Minister.

2. The organizing body can through the form of foundations, associations, and other forms in accordance with the provisions of the legislation.

3. PTS establishment must meet minimum standards of accreditation.

4. PTS established shall have the Statute.

PTS Statute stipulated by the decree of board organizer (Article 66 section 3Law No.12/2012). Further regulations on PTS establishment are in (Article 60,section 7Law 12/2012). As the ruled by Article 7 section (5), Article 24 section (6), Article 25 section (6), Article 26section (8), Article 43 section (4), Article 60 section

(7), and Article 68 Law No 12/2012, President SusiloBambangYudhoyono on 30 ${ }^{\text {th }}$ January 2014 signed Government Regulation No. 4/2014 on the Implementation of the Higher Education and Management of Higher Education.

The regulation of college organizer include; A)the responsibilities, duties, and authority of the Minister of Education and Culture in the Implementation of Higher Education, B)Establishment of University, Study Program, and the Program of Higher Education. C)the degree, diploma, and certificate of the profession. While the regulation of College Management includes: A)Autonomous University, B)The College of Management, C)Governance of Higher Education, D)public accountability.

The regulation explained about the responsibility of the Minister of Education and Culture toward Higher Education includes Management, Planning, Controlling, monitoring, evaluation, Development, and coordination. Article 4 of the regulation confirms, in carrying out the responsibilities in the term of regulation, the Education Minister has the duty and authority to regulate the system of higher education, the budget for Higher Education, the rights of students, access to justice, the quality of higher education, the relevance of higher education, and the availability of higher education.

Based on the description above, the writer conducted two problems of the study, as bellows:

1. How does the authority of higher education in Indonesia?

2. How an internal conflict resolution private universities in Indonesia?

A. Regulation Authority toward CollegeManagement in Indonesia

1. Regulation Authority toward College Management in the Law Republic of Indonesia No. 22/1961 on Higher Education

social involvement in the effort educating the nation through the establishment of PTS has done before.

To create PTS order management, the government gradually began to set the PTS through legislation, such as No.23/1959 On Regulations of State Examination Obtaining a degree for Students of Private Higher Education. 
Colleges which meet the requirements are a). higher education in the form of a legal entity, foundation or association which has been recognized by the Government, b). has registered its establishment to Ministry and ongoing for at least 3 years, c). The learning method for each branch subject is the same as subjects at the Faculty of State, D). the same arrangement with the composition faculty lecturer at the Faculty of State and the quality of his skills recognized by the Faculty of the State.

In 1961, the Government made improvements to the rules through Law No. 22/ 1961 on Higher Education. The birth of this law is a major forward step in the history of higher education in Indonesia for the first time higher education objectives defined by law, namely:

A. Establishing human decency spirit of Pancasila and responsible for the establishment fair and prosperous toward Indonesian social life, both materially and spiritually.

B. providing up power capable of taking office requiring higher education, and a capable stand-alone in maintaining and advancing science.

C. Conduct research and business progress in the field of science, culture and social life (law considering No. 22/1961). [7]

PTS would receive the status Registered if the founder has informed about the establishment of the PTS to the Minister by submitting a notary certificate of organizer foundation, statutes, property and/or source of income that is destined to run the college, study plans and a list of lecturers with the education and employment history and the lessons that it provides a maximum of six months starting from the PTS was founded [8]. PTS which status is Registered cannot hold the examination independently. While the PTS with recognized status is allowed to conduct its own examination with guidance and supervision of the Ministry, and the diplomas have the same value with the State University, while the PTS with Lumped status of the right to conduct its own examinations and promotions with the same result with an exam and promotions on PTN. Gradually, PTS Registered be set to be recognized, then can be set into Lumped status by the Minister throughout the recommendation of LPTS. [9]

Due to the increasingly PTS widespread at the time, the government issued new rules in terms of the establishment of PTS to protect citizens from irresponsible PTS, Presidential Decree No. 15/1965 On the private Colleges Establishment. Which purposed in tightenedHigher education organizer who wants to organize higher education must obtain written agreement from the Minister of Higher Education and Science. [10]

As the real fact, To meet the demands of the Indonesian revolution in 1960, the President issued a Presidential DecreeNo 19/1965 About the basic National Education System based on Pancasila. The decree Stated that education is the integral part of the revolution which should hold function as: (1) Fostering the new Indonesian life to high morals, (2) Manufacturer manpower in all fields and levels, (3) National Institute of Cultural development, (4) Organization concerning on development of science, engineering and physical / mental; and driving the entire power of all nation. [11]

In other side, To improve the implementation and development of higher education related to development of university /state institute, the Government issued laws 5/1980 on the Principles of Organization of University which regulates the university statute, duties, and functions, about organizational structure such as rector, provost, board of faculty/department, and about the board of social services (LPM). Dealing with the decree, as the tribute to the positive efforts made by the PTS in carrying out the three responsibilities of Higher Education (learning, researching, and social service) Government issued PP 39 of 1982 on Providing fund Assistance to the College.

\section{Regulation Authority toward College Management in the Law of the Republic of Indonesia No.2/1989 on National Education System}

To meet the needs and demands of the national education development as the system ordered to strengthen national defense and to realize advance society toward national culture and national unity-minded based on Pancasila and the 1945 Constitution, in 1989, the Government implemented the Act No. 2/1989 on National Education System (hereinafter referred to as "UU SPN"), the Law bring several significant changes on education. Such as government regulation(PP) 30/1990 on Higher Educationwhich proposesthe regulation on PTN and PTS simultaneously.

The Completion of the PP 30/1990 was carried out by issuing PP 57/1998. The Rules provides the Government authority to cancel the appointment of the Rector/Chief/director of the college which organized by the Society if the appointment does not meet the requirement. In addition, in 1999 government altered the law by issuing PP 60/1999 on Higher Education. Some of the changes include the period of the Dean and the department chief that previously 3 years into 4 years, and about faculty academic hierarchy, where the PP 30 , 1990 consisted of Assistant, Lector, and Professor into Assistant, Lector, Lector -chief and Professor. 
Government's intention to give autonomy to the PTNdone through PP 60/1999Mentioned that the college organized by the Government has been able and worthy to be managed independently can be assigned legal status to an independent legal entity. This is then followed up by issuing PP 61/1999 on the State-owned legal entity (BHMN). Concretely, the way to achieve this is by requiring all educational units are legal entities education as stipulated in Article 53 Paragraph (1) UUSPN. This article literally became the basis of enactment of the Law No. 9/2009 on the Legal entity of Education (hereinafter referred to as BHP).

In the real condition, the are many kinds social rejection toward enactment this law (BHP), the Rejection finally ended in the Constitutional Court which terminated on $31^{\text {st }}$ March 2010 with decision No. 1114-21-126-136/PUU-VII/2009, stating that Law No.9/2009 on BHP is contrary to the Constitution 1945. As the consequence, the PT-BHMN must be returned into the PTN. Hence, Education University of Indonesia and Institute Technology of Bandung which previouslyasPT-BHMN settled back into higher education organized by the government (PTN). Dealing with a cancellation of UUBHP, the Government revised the PP 17/2010 into PP 66/2010 with several improvements including the addition of several provisions, including on access to education, scholarships, educational assistance for Indonesian citizens and foreigners, and state university management.

\section{Regulation Authority toward College Management in the Law of the Republic of Indonesia No. 12/1989 on Higher Education}

the Substance of laws No. 12/2012 on Higher Education needs to look at some texts based on the problem interest, for example in Article 50. The substance of the Articles the government effort to introduce globalization in education. Due with this, before the national education really ready to lead there, we must define full-comprehensive what it is the globalization itself?. Generally, globalization defines as westernization or modernization, namely the spread to the whole world concerning the structure of western modernity, capitalism, rationalism, industrialism, bureaucratism, and others that tend to damage the existing local culture first.

On the other hand, Article 62 section (1) states, the university has autonomy to manage its own institutions as central entity realizing Tridharma. Section (2) states, autonomous management of universities as referred to in section (1) shall be implemented in accordance with the basis and purpose as well as the College ability. Section (3) states, the basis, and purpose, as well as the ability of the college to implement the autonomy, referred to in section (2) independently evaluated by the College. Section (4) states, for further provisions regarding the university evaluation, objectives, and ability to implement the autonomy as the referred to in section (3) shall be stipulated in the Ministerial Regulation.

Article 63 states, autonomous management of Higher Education carried out based on the principles of accountability, transparency, non-profit, quality assurance, as well as effectiveness and efficiency. Meanwhile, in Article 64 stated:

A. Autonomous University management as referred to in Article 62 covering either academic or non-academic field.

B. Autonomous management in the academic field as referred to in paragraph (1) include the establishment of norms and operational policy as well as the implementation of the Tridharma.

C. Autonomous management in the non-academic field as referred to in paragraph (1) include the establishment of norms and operational policy and the implementation of organizational, financial, student affairs, staff, and infrastructure.

Autonomous attendance in the management of Higher Education is a clear form of the empty responsibility from the state. This case is dealing with Foreign corporate logic which states that privatization is included in the concept of liberalization.

In the ruling decision No 11-14-21-126-136/PUU about the cancellation of UU BHP, Court of law states, the term of "Educational Legal Entities (BHP)" as referred to in Article 53 section (1) of the Law on National Education System (UU Sisdiknas) is not the certain name and legal form, but rather the designation of education function which means the educational institution should be managed by a legal entity. As for the legal entity can be various well as regarding upon the forms known in the legislation, such as foundations, associations, trusts, endowments agencies, and so on. Therefore, elucidation of Article 53 section 1on UU Sisdiknas becomes useless because of the explanation of the Article above is narrowing the meaning of BHP and contrary to the intent of the Article. Thus, according to the Court, the Petitioners' arguments has legal 
grounds as well as the definition of BHP in Article 53 section 1not interpreted as the certain name and legal form, but the designation of the function of education organizer, which means that an educational institution shall be managed by a legal entity. It means the legal entity should perform the function of education management to the community, not as an institutional form that gets special access.

\section{B. Internal Conflict Resolution toward private college in Indonesia}

\section{Regulation of Conflict Resolution through Non-Litigation}

In order to resolve the PTS dispute out of court, it may use alternative mechanisms as stipulated in Law No.30/1999 on Arbitration and Alternative Dispute Resolution. Alternative dispute resolution is an institution for settling disputes in a procedure agreed by the parties. Namely, the settlement by way of court through consultation, negotiation, mediation, conciliation or expert judgment.

\section{A. Negotiation}

Generally, the negotiations can be interpreted as an attempt to resolve the dispute parties without through the judicial process with the aim achieving a mutual agreement on the basis of a more harmonious cooperation and creative. The term of the negotiations: (1) the implementation of the negotiations depends on the freedom or the will of both the parties; (2) the parties are also free to determine at what stages of a negotiation is deemed to have resolve disputes; and (3) the binding power of a settlement also ultimately depend on the free will or good intentions of the both parties have agreed to negotiate. In the negotiation process, the dispute parties hold the legislation directly without assistance of third parties, although they may be accompanied by their lawyer. Dispute resolution is fully controlled by the parties themselves to reach an agreement.However, The Failure resulting from direct negotiations can aggravate the dispute.

\section{B. Mediation}

The Definition of mediation explained in Article 1 section (6) of supreme court regulation No. 1/2008 on Mediation Procedures in the Court, "the mediator is a neutral third party who assists the parties in the negotiation process for the various possibilities of dispute resolution without the use of a way of breaking or impose a settlement". Then in Article 1 paragraph (7) stated: "mediation is a way of resolving disputes through negotiation process to obtain the agreement of the parties with the assistance of a mediator".

In the other word, the mediator should remain neutral position, always fostering good relations, speak use the parties language, listen actively, emphasizing the potential advantages, minimize differences, and emphasizing similarities. The goal is to help the parties negotiations is better on a settlement. Concerning the mediator determines the effectiveness of the process dispute resolution, the mediator should meet certain qualifications and experience in communication and negotiation in order to be able to direct the dispute parties. Moreover, if the mediator has experience and accustomed to litigating in court, it's very helpful. This was due to the parties who cannot resolve disputes itself uses the neutral third party to help them reach an agreement.

\section{Conciliation}

Conciliation is to submit to the dispute resolution to the committee of people whose job is to describe or explain the facts and make proposals for a settlement. But the decision was not binding.

\section{Regulation of Conflict Resolution through Litigation}

Legal justice does not necessarily run without the institutions that implement them. In the context of Indonesian law, justice organized by the court as a medium to get justice. For the role of the judiciary in upholding justice is a necessity. So, the court is forced to make abstract justice ideas [12]. Juridically Article 2 section (2) Law No. 48/2009 on the second amendment of Law No. 4/2004 on Judicial Power states that "Justice States implement and enforce the law and justice based on Pancasila".

Accordance with the principles of legitimate persona standing in judicial, everyone is entitled to become a party (plaintiff) to act in the court to obtain their right that infringed by other parties. As the plaintiff in the lawsuit filed must be filled at least two main points; the existence of an interest and the existence of a legal relationship [13]. It means that the lawsuit or claim existing rights and legal interests are granted by the court, but still depends on the evidence. When demand is proved right by a pedestal right, the demand can be granted. Therefore, to be granted the right or the lawsuit claims is depending on the results of verification.

Dealing with this, Proof become a central focus for the success or failure of a filing claims or claim rights. in the process of evidence, the proved is the event not the law - jus in causa posit um which means in the event that there is a legal [14]. About the law does not need to be proven, the judge deemed to know the law (ius curia Novit). Thus, the purpose of verification is to seek certainty about the events or acts that occurred. Through the proved events or acts, the judge applying the law as outlined in the decision. 
By the mutual authentication system, the party was placed in an opposite position, even in hostile because each party tried to outperform each other. Therefore, the results or output of the process, the court rarely can meet or grant the wishes of both parties to provide mutual decision (win-win solution). Generally, according to the results of evidence the judge should and must be settled grant or win one of the parties and by itself, it must defeat the other party. For those who has granted lawsuit would say "win". So, the word or phrase of justice that has been a goal or output of the verification process used in the opinion of appreciation and interpretation of law altered into a victory. In such process and meanings, the parties do not hunt justice anymore. Justice has been replaced and was left behind by other forms of expression namely "win or lost". [15]

\section{Conclusion}

Based on the discussion and the descriptions above, the following can be concluded:

First; regulation of authority toward private higher education can be found at: (1) Law of the Republic of Indonesia No 22/1961 on Higher Education; (2) Law of the Republic of Indonesia No 2/1989 on National Education System; and (3) of the Constitution of the Republic of Indonesia No 12/2012 on Higher Education; Secondly; the resolution of the internal conflict of private higher education can be through two terms. First, through non-litigation: the settlement outside the court that include negotiation, mediation, conciliation, and arbitration. Second, through litigation: the settlement takes process to place on the court.

\section{References}

[1]. KamusBesarBahasa Indonesia Versi Daring, http://kbbi.web.id/didik.Accesed in 9 June 2016

[2]. Ki Hajar Dewantara. 1977.Karya Ki HajarDewantara. Yogyakarta: MajelisLuhur TamanSiswa. P. 14

[3]. Section 1 general point of Sisdiknas law

[4]. Pendidikantinggi, https://id.wikipedia.org/wiki/Pendidikan_tinggi

[5]. UharSuharsaputra, ManajemenPendidikanPerguruanTinggi, Bandung: PT. RefikaAditama, 2015, P. 28

[6]. law No. 12/2012, section 24

[7]. considerancelaw No. 22/1961

[8]. section 26 law No.22/1961 on higher college

[9]. section 27 law No.22/1961 on higher college

[10]. considerance regulation of president indonesianrepubic No. $15 / 1965$ on private higher college

[11]. considerance of president decree No.19/1965 on the points system of pacasila national education

[12]. Satjipto Rahardjo.2007,Konstribusi Lembaga Sosial Mendorong Reformasi Peradilan, dalam Bunga Rampai: KomisiYudisialdanReformasiPeradilan, KomisiYudisialRepublik Indonesia. P. 70

[13]. Sudikno Mertokusumo. 2010. Hukum Acara perdata indonesia, yogyakarta: UniversitasAtma Jaya Yogyakarta, P. $42-43$

[14]. John Z Loudoe, Menemukan Hukum melalui Tafsir dan Fakta, Jakarta: Bina Aksara, 1985, hlm. V

[15]. M. Yahya Harahap, "Dua Sisi Putusan Hakim Tidak Adil Bagi Yang Kalah Dan Adil Bagi Yang Menang”, Majalah Varia Peradilan, Jakarta: Ikahi, Edisi No.95), P. 103. 